\title{
Effects of seismic ground motion and geological setting on the coseismic groundwater level changes caused by the 1999 Chi-Chi earthquake, Taiwan
}

\author{
Wen-Chi Lai ${ }^{1}$, Naoji Koizumi ${ }^{2}$, Norio Matsumoto ${ }^{2}$, Yuichi Kitagawa ${ }^{2}$, Ching-Wee Lin ${ }^{1}$, Chjeng-Lun Shieh ${ }^{1}$, and Youe-Ping Lee ${ }^{3}$ \\ ${ }^{1}$ Disaster Prevention Research Center, National Cheng Kung University, Taiwan, R.O.C. \\ ${ }^{2}$ Tectono-Hydrology Research Group, Geological Survey of Japan, National Institute of Advanced Industrial Science and Technology (AIST), Japan \\ ${ }^{3}$ Water Resources Agency, Ministry of Economic Affairs, Taiwan, R.O.C.
}

(Received November 15, 2002; Revised July 5, 2004; Accepted July 14, 2004)

\begin{abstract}
The groundwater level changes induced by the 1999 Chi-Chi earthquake were well recorded at the monitoring wells in and around the Choshui River alluvial fan, Taiwan, which is adjacent to the focal region. We analyzed the coseismic groundwater level changes related to the geological setting and seismic ground motion. In a typical fan area, the groundwater levels coseismically rose and those amplitudes increased as the ground acceleration and hydraulic conductivity became larger. In the slope area near the earthquake fault, the groundwater levels coseismically dropped and those amplitudes increased as the ground acceleration became larger. The liquefaction and permeability enhancement, whose degrees depend on the geological setting and seismic ground motion, might explain the characteristics of the coseismic groundwater level changes in the Choshui River alluvial fan.

Key words: Chi-Chi earthquake, liquefaction, geological setting, ground motion, hydrologic conductivity, permeability enhancement.
\end{abstract}

\section{Introduction}

The groundwater level changes induced by earthquakes have been well reported in the historical records and precisely monitored for the last 20-30 years in China, Japan, the U.S.S.R. and the United States (e.g., Wakita, 1975; Roeloffs, 1988, 1996). The study for the water-level changes is also important to some natural hazards related to earthquakes. Examples are landslides and debris flows after an earthquake, liquefactions of soil and groundwater pollution caused by mixing of radioactive wastes or other high-risk wastes (Carrigan et al., 1991; Inverson and Major, 1986; Todorovska and Trifunac, 1999). Since the earthquakerelated groundwater level changes were scattered and rarely observed by a sufficiently dense network of observation wells, such studies have not been adequately developed.

On 21 September, 1999, a large earthquake with Mw 7.6 occurred near Chi-Chi in central Taiwan at 1:47 a.m. local time, and it was named the Chi-Chi Earthquake (Shin et al., 2000) (Fig. 1). The Chi-Chi earthquake is a rare welldocumented event for earthquake-induced groundwater level changes together with abundant seismological data sets. The groundwater level changes induced by the Chi-Chi earthquake were first reported by the Water Conservancy Agency (2000). Based on the hourly digital record of the water levels, the Agency reported that all the changes were coseismic or postseismic. Chia et al. (2001) describes the details of the groundwater level changes in hourly digital records and

Copy right (C) The Society of Geomagnetism and Earth, Planetary and Space Science (SGEPSS); The Seismological Society of Japan; The Volcanological Society of Japan; The Geodetic Society of Japan; The Japanese Society for Planetary Sciences; TERRAPUB analog records and compared the coseismic changes with the distances between the earthquake fault and observation wells. Wang et al. (2001) discussed the distribution of the coseismic groundwater level changes and tried to explain the groundwater level changes by liquefaction. This mechanism could partially explain the coseismic changes, but we think that it is insufficient to explain the spatial distribution of them.

In this study, we will compare the coseismic groundwater level changes with seismic ground motion and geological setting. The distributions of the coseismic changes in different places and aquifers will enable us to discuss the effect of the geological setting on the coseismic changes. Comparing them with the hydraulic conductivities and peak ground accelerations will also show how the seismic ground motion and geological setting affect the coseismic groundwater level changes.

\section{Observation}

The studied area was first divided into two parts. One part is a typical alluvial fan, and the other part is the slope area (Fig. 1). In the slope area, which is composed mainly of terrace deposits or Pleistocene gravel layers, there are no clear boundaries for aquifers. The aquifers in the slope area have lower hydrological conductivities (Water Resources Bureau, 1999) than most of those in a typical fan (Table 1).

The Choshui River alluvial fan is located on the west coast of central Taiwan (Fig. 1), composed of alluvial to shallowmarine facies deposits in the age of Holocene to Pleistocene (Chen and Yuan, 1999). The Choshui River alluvial fan has been considered to consist of four main aquifers divided by three aquitards (Water Resources Bureau, 1999). Due to the 


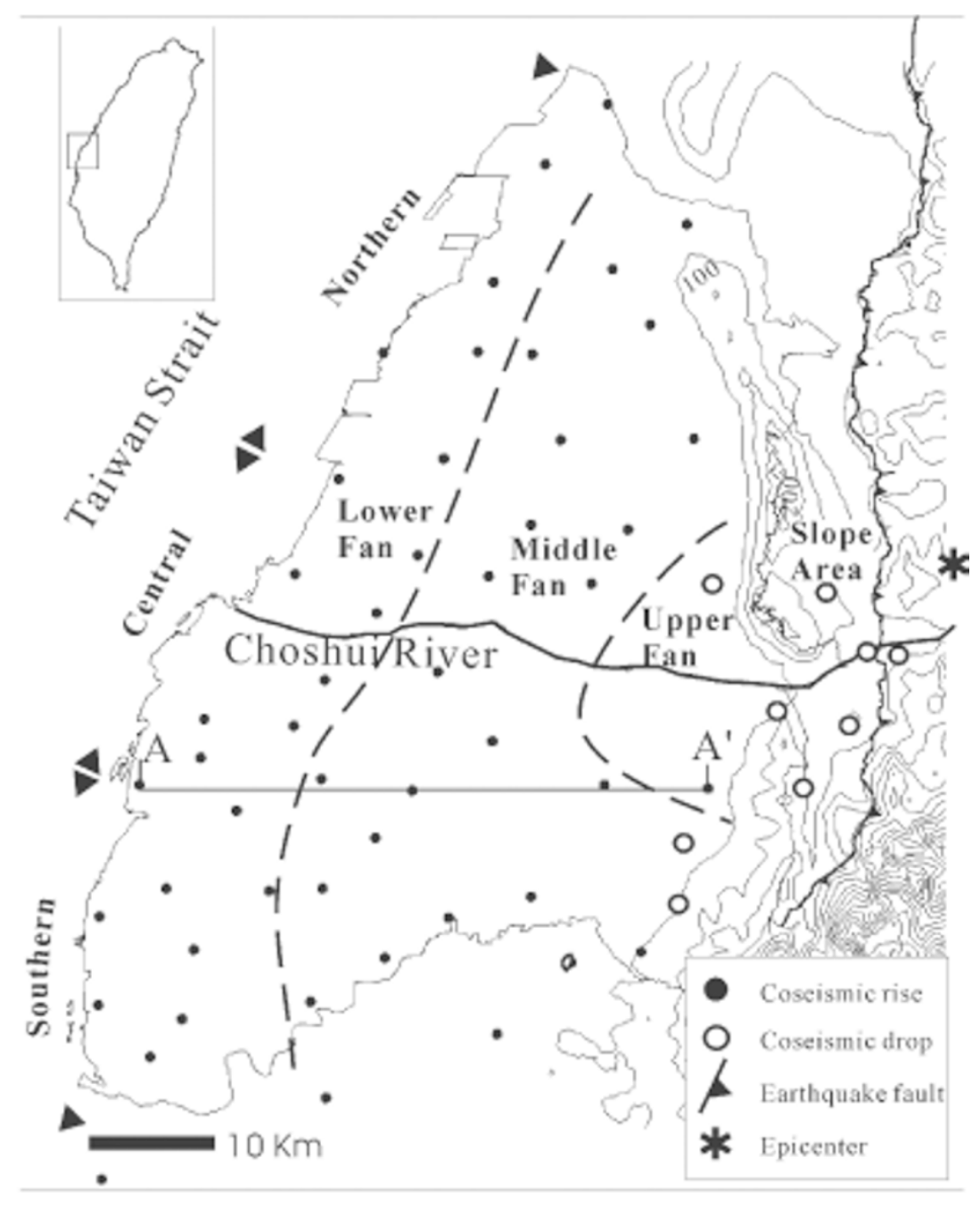

Fig. 1. Location of the Choshui River alluvial fan, position of the monitoring wells and the epicenter of 1999 Chi-Chi earthquake $($ Mw $=7.6$, Depth $=7$ $\mathrm{km})$. This figure is modified from Chia et al. (2001). Coseismic drops and rises in the groundwater levels are represented by open and solid circles, respectively. Section A-A' shows the location of the cross-section in Fig. 2.

Table 1. Average hydrological conductivities of the Choshui River alluvial fan $(\mathrm{m} / \mathrm{sec})$.

\begin{tabular}{|c|c|c|c|c|c|c|c|c|}
\hline Aquifer & Slope Area & Upper-Fan Area & $\begin{array}{c}\text { Northern } \\
\text { Middle-Fan Area }\end{array}$ & $\begin{array}{c}\text { Central } \\
\text { Middle-Fan Area }\end{array}$ & $\begin{array}{c}\text { Southern } \\
\text { Middle-Fan Area }\end{array}$ & $\begin{array}{c}\text { Northern } \\
\text { Lower-Fan Area }\end{array}$ & $\begin{array}{c}\text { Central } \\
\text { Lower-Fan Area }\end{array}$ & $\begin{array}{c}\text { Southern } \\
\text { Lower-Fan Area }\end{array}$ \\
\hline Layer 1 & $5.70 \times 10^{-5}$ & $10.81 \times 10^{-4}$ & $7.76 \times 10^{-4}$ & $7.56 \times 10^{-4}$ & $2.74 \times 10^{-4}$ & $2.49 \times 10^{-4}$ & $3.62 \times 10^{-4}$ & $2.12 \times 10^{-4}$ \\
\hline Layer 2-1 & $7.35 \times 10^{-5}$ & $9.10 \times 10^{-4}$ & $5.36 \times 10^{-4}$ & $6.48 \times 10^{-4}$ & $2.09 \times 10^{-4}$ & $3.18 \times 10^{-4}$ & $4.16 \times 10^{-4}$ & $3.15 \times 10^{-4}$ \\
\hline Layer 2-2 & $3.23 \times 10^{-6}$ & $8.78 \times 10^{-4}$ & $3.71 \times 10^{-4}$ & $5.07 \times 10^{-4}$ & $2.00 \times 10^{-4}$ & $5.99 \times 10^{-4}$ & $3.81 \times 10^{-4}$ & $1.52 \times 10^{-4}$ \\
\hline Layer 3 & $6.91 \times 10^{-5}$ & $8.37 \times 10^{-4}$ & $3.34 \times 10^{-4}$ & $3.55 \times 10^{-4}$ & $5.07 \times 10^{-5}$ & $5.03 \times 10^{-4}$ & $5.46 \times 10^{-4}$ & $2.58 \times 10^{-4}$ \\
\hline Layer 4 & - & - & $3.12 \times 10^{-4}$ & $2.88 \times 10^{-4}$ & $6.45 \times 10^{-5}$ & $2.53 \times 10^{-4}$ & - & $2.01 \times 10^{-4}$ \\
\hline
\end{tabular}

After Water Resources Bureau (1999).

characteristics of alluvial sediments, most of these aquifers and aquitards are contacted in fingered shapes (Fig. 2). The fine-grained sand, silt and mud became the aquitard between the coarse-grained sands and gravels. Layer 1 is mostly an unconfined or partial confined aquifer. Layer 2, which is also divided into layers 2-1 and 2-2, layer 3 and layer 4, have been considered to be partially confined or well confined (Hsu et al., 2000). Since these layers' groundwater levels widely fluctuated by pumping, it is difficult to estimate strain sensitivities of the groundwater levels by the analysis of tidal or barometric responses.
The Choshui River alluvial fan is also divided into the upper-fan, middle-fan and lower-fan areas based on the difference of the hydrological and geological settings (Water Resources Bureau, 1999). In the upper-fan area, the sediments are mainly composed of thick gravel layers with a high hydrological conductivity (Table 1). In the middle-fan area, the main constituents in the north and central parts (Fig. 1) are thick sands and gravels with some silts and muds. The southern part of the middle-fan area is mostly composed of medium-to-fine-grained sands and silts. The lower-fan area is mainly composed of marine-facies silts and mud deposits, 


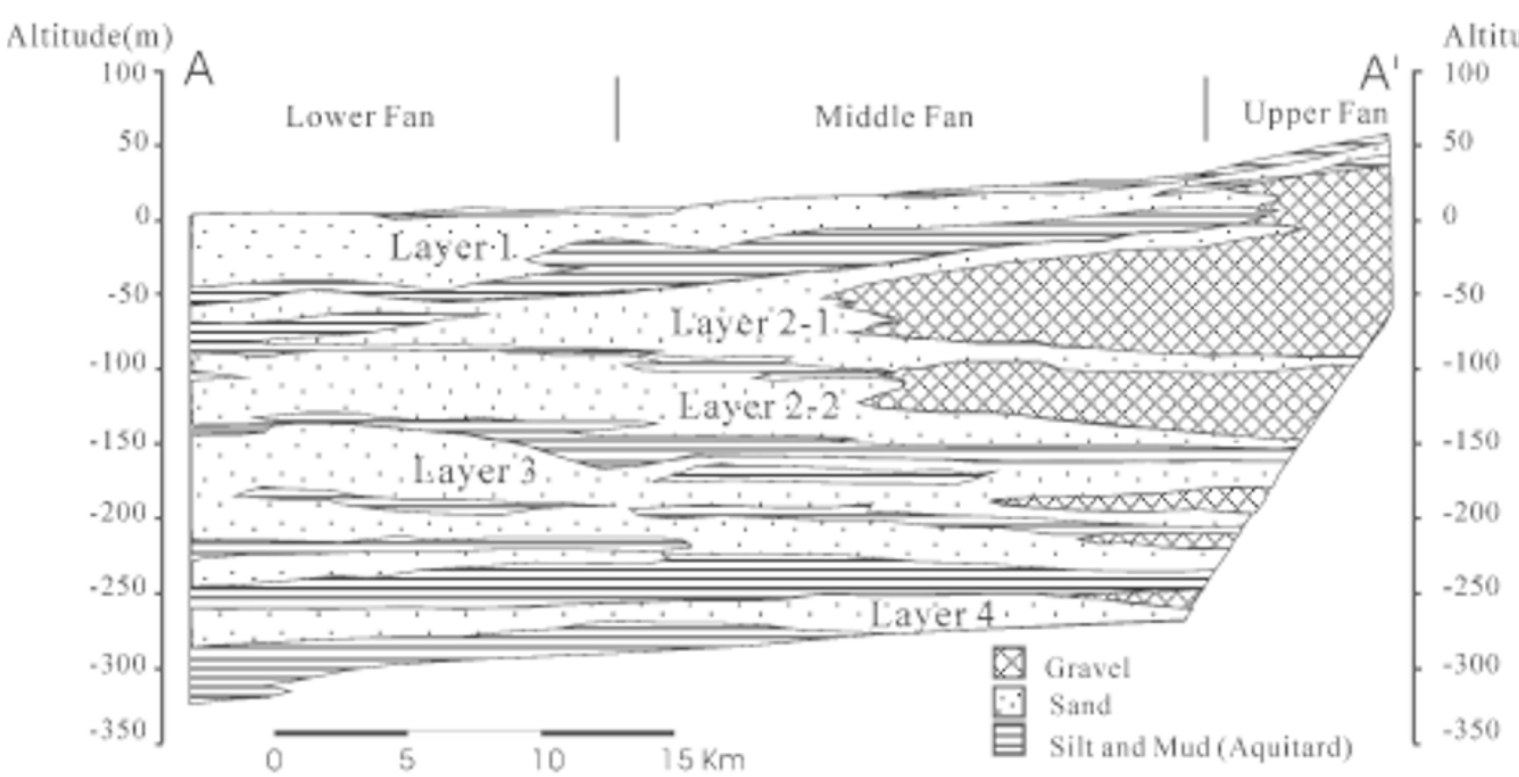

Fig. 2. Hydro-geological cross-section along line A-A' in Fig. 1. The cross-section shows the composition of hydrological units in the Choshui River alluvial fan, which is simplified from Hsu et al. (2000).

but a few of the thin layers containing sands and gravels exist in the northern and central areas of the lower-fan. Those different geological settings reflected different hydrological conductivities of the aquifers in the studied area (Table 1), which were measured before the 1999 Chi-Chi earthquake.

The total number of observation wells in the studied area is 188 , which are distributed at 73 stations (Water Resources Bureau, 1999). Since some wells were not in operation and some wells lost records just before and after the Chi-Chi earthquake, we used the water level records at 168 wells in this study. Each well has a single screen in a single aquifer. The depths of the wells range between 15 and $306 \mathrm{~m}$. The groundwater levels have been recorded on digital data loggers hourly or strip-chart analog recorders in a resolution of 5 minutes. The resolution of the water level data is $2 \mathrm{~cm}$.

The Chi-Chi earthquake was well recorded by a dense network of three-component accelerators of Taiwan (Shin et al., 2000). We estimated a peak ground acceleration (PGA) at each observation well using the records of 384 accelerator stations in the network by linear interpolation.

\section{Results}

The water level changes show both steplike and oscillatory patterns (Chia et al., 2001). The oscillatory changes happen mostly in the shallow unconfined aquifers. In the deeper aquifers, the changes show a step-like pattern. The groundwater level very abruptly rises or falls within five minutes after the main shock (Chia et al., 2001). Many large aftershocks followed the main shock especially after 2 o'clock on 21 September, 1999 and not all of the wells had the ana$\log$ recorders. In order to discuss all the coseismic changes caused by the main shock under the same condition, we regard the hourly difference between 1:00 and 2:00 am on 21 September as a "coseismic change". These coseismic water level changes in the Choshui River alluvial fan widely ranged from -11.09 to $7.42 \mathrm{~m}$ (Fig. 3).

For the shallow unconfined aquifers, the groundwater level rose back to the original level in a duration of 1 to 2 hours. But for the deeper aquifers or partially confined shallow aquifers, the duration ranges from 1 to 6 months. Some of the wells had permanent changes in the groundwater level of about several meters. This may probably depends on the properties of the aquifers. For example, the short recovery time for the unconfined aquifers is considered to show easier flow occurrence or quicker diffusion in the unconfined aquifer than that in the confined.

The comparison of the coseismic changes with the distances between the observation wells and fault (Fig. 3) showed a certain pattern. The larger the coseismic rises became, the nearer the observation wells to the earthquake fault. But this tendency stopped at a distance of 10-20 km and the changes decreased after that. The coseismic changes dropped when the distances were smaller than $10 \mathrm{~km}$. This pattern was also reported by Chia et al. (2001). In addition, the coseismic changes in layer 1 showed a different pattern from the other layers. They had smaller coseismic rises than the other deeper layers but similar or larger coseismic falls (Fig. 3).

It is interesting that the larger coseismic rises and falls made narrow zones, which were sub-parallel to the earthquake fault (Fig. 4). Figure 4 shows that the coseismic rises and drops were observed mainly in the typical fan area and the slope area, respectively (Fig. 1). There are clearly different coseismic changes between the northern, central and southern parts of the fan. In the northern and central parts, the coseismic rises are larger, although those in the southern part are smaller (Fig. 4 and Table 2) (Chia et al., 2001). This might be caused by a difference of the hydrological conductivities (Table 1), which is also a reflection of the geological differences as described above, because larger hydraulic conductivities tend to produce bigger coseismic rises in the typical fan area (Fig. 5). It is probably because larger hydraulic conductivity makes it easy to turn pore-pressure change in the layer into water-level change in the well. The reason is 


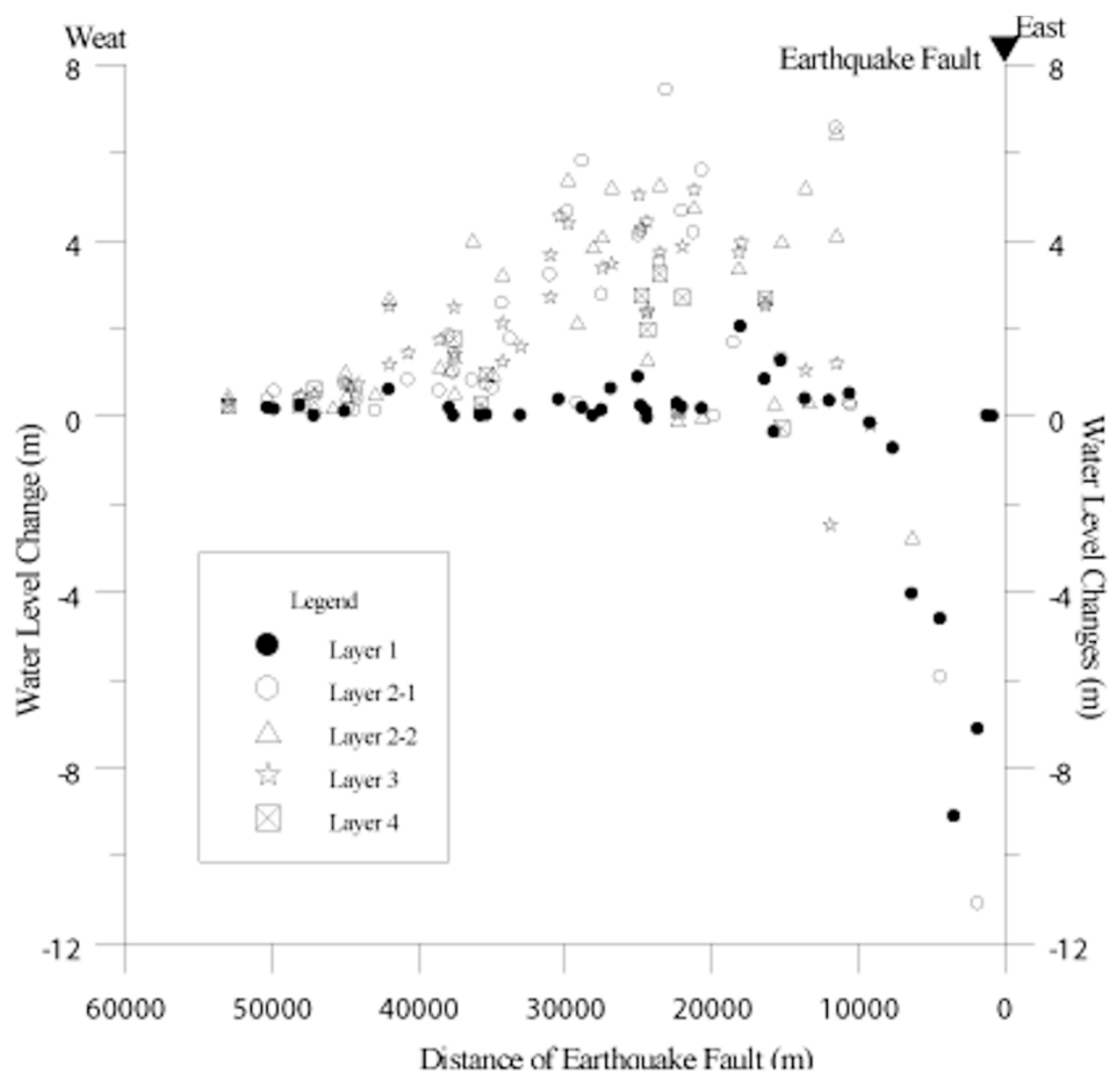

Fig. 3. Coseismic water level changes in the different aquifers relative to the distances between the observation wells and earthquake fault.

Table 2. Average coseismic groundwater level changes of the Choshui River alluvial fan (m).

\begin{tabular}{lcccccccc}
\hline \multicolumn{1}{r}{ Aquifer } & Slope Area & Upper-Fan Area & $\begin{array}{c}\text { Northern } \\
\text { Middle-Fan Area }\end{array}$ & $\begin{array}{c}\text { Central } \\
\text { Middle-Fan Area }\end{array}$ & $\begin{array}{c}\text { Southern } \\
\text { Middle-Fan Area }\end{array}$ & $\begin{array}{c}\text { Northern } \\
\text { Lower-Fan Area }\end{array}$ & $\begin{array}{c}\text { Central } \\
\text { Lower-Fan Area }\end{array}$ & $\begin{array}{c}\text { Southern } \\
\text { Lower-Fan Area }\end{array}$ \\
\hline Layer 1 & -2.81 & 3.12 & 0.94 & 0.36 & 0.05 & 0.29 & 0.26 & 0.11 \\
Layer 2-1 & -4.92 & 0.12 & 3.89 & 3.15 & 0.81 & 3.37 & 0.90 & 0.44 \\
Layer 2-2 & -1.81 & - & 4.74 & 2.28 & 0.71 & 3.70 & 1.87 & 0.60 \\
Layer 3 & -0.19 & - & 3.20 & 3.49 & 2.36 & 3.02 & 1.55 & 0.90 \\
Layer 4 & - & - & 1.49 & 1.82 & 1.06 & 2.73 & - & 0.62 \\
\hline
\end{tabular}

After Water Resources Bureau (1999).

that groundwater flow between the layer and well actually makes the water level change in the well.

At a few of the stations in the typical fan area, coseismic falls and rises were observed at different depths in the same station (Fig. 4). In most cases, the coseismic drops in the layer 1 and rises in the other deeper layers were observed (Fig. 4).

\section{Discussion}

A reverse faulting, which is a main characteristic of the Chi-Chi earthquake (Ma et al., 2001), is generally expected to cause dilatation in the area in front of the fault if it reaches the surface (e.g., Iwasaki and Sato, 1979). Therefore, the strain-induced groundwater levels are inferred to drop there. However, the groundwater levels in the Chusuishi alluvial fan in front of the Chi-Chi earthquake fault rose coseismically. Moreover, the area of liquefaction was found in the Choshui River alluvial fan (Wang et al., 2001), which would cause groundwater-level rises. Therefore, Wang et al. (2001) attributed the coseismic groundwater-level changes not to the coseismic volumetric strain changes but to the liquefaction. On the other hand, based on the distribution of coseismic strain changes calculated from the fault model of Ma et al. (2001), which showed that the Choshui River alluvial fan was the coseismic contraction area contrary to the above usual sense, Lee et al. (2002) maintained that the coseismic groundwater level changes were caused by the coseismic volumetric strain changes. Koizumi et al. (2004) recalculated the coseismic volumetric strain changes from the fault model of Ma et al. (2001) and the result showed that the polarities 


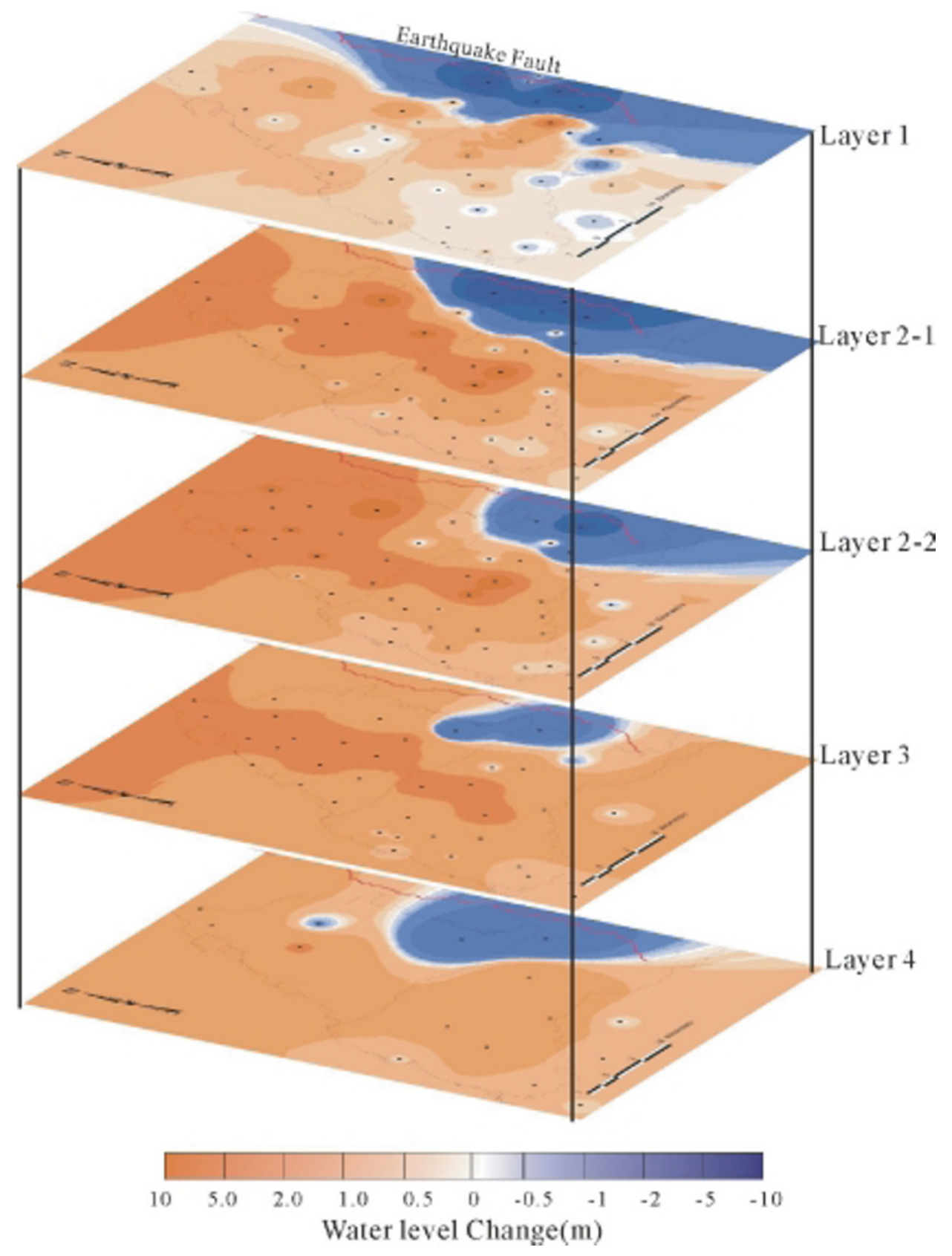

Fig. 4. Distribution maps of the coseismic water level changes and monitoring wells in different aquifers; the division of each aquifer follows the Water Resources Bureau (1999). Black points show locations of the wells. The red line shows the earthquake fault.

of the recalculated ones were the reversal of Lee et al. (2002) and supported Wang et al. (2001).

Since the strong seismic motion over a certain threshhold tends to make the sediments dilate, Wang et al. (2001) also attributed the coseismic drops in the slope area, which is adjacent to the earthquake fault, to the strong seismic motion and ignored the effect of the fluid flow. However, since the preseismic or original gradient of the hydraulic head was very large in the slope area (Fig. 6), it seems possible that immediate falls in the groundwater level at the slope area should be caused by groundwater flow induced by seismic permeability enhancement (Rojstaczer and Wolf, 1992; Sato et al., 2000). As mentioned above, the coseismic changes in layer 1, which is almost unconfined, were smaller rises in the fan area and larger falls in the slope area. Since it can be explained by the effect of flow or diffusion, which is easier to occur in unconfined aquifers than in confined, we think that the effect of the fluid flow should exist. Several coseismic drops at the layer 1 in the typical fan area might also be caused by the effect of the local flow or diffusion.

Since both of the liquefaction and permeability enhancement are caused by seismic shaking, the coseismic groundwater changes should be closely related to the seismic ground acceleration under the same geological setting. The coseismic changes in all layers were actually closely related to the three-components (i.e. vertical, east-west and northsouth direction) of the acceleration. These changes in the deeper layers (layer 2-1, layer 2-2 and layer 3) and the vertical accelerations show a unique relationship (Fig. 7(a)). This shows a similar pattern to that shown in Fig. 3 because the 


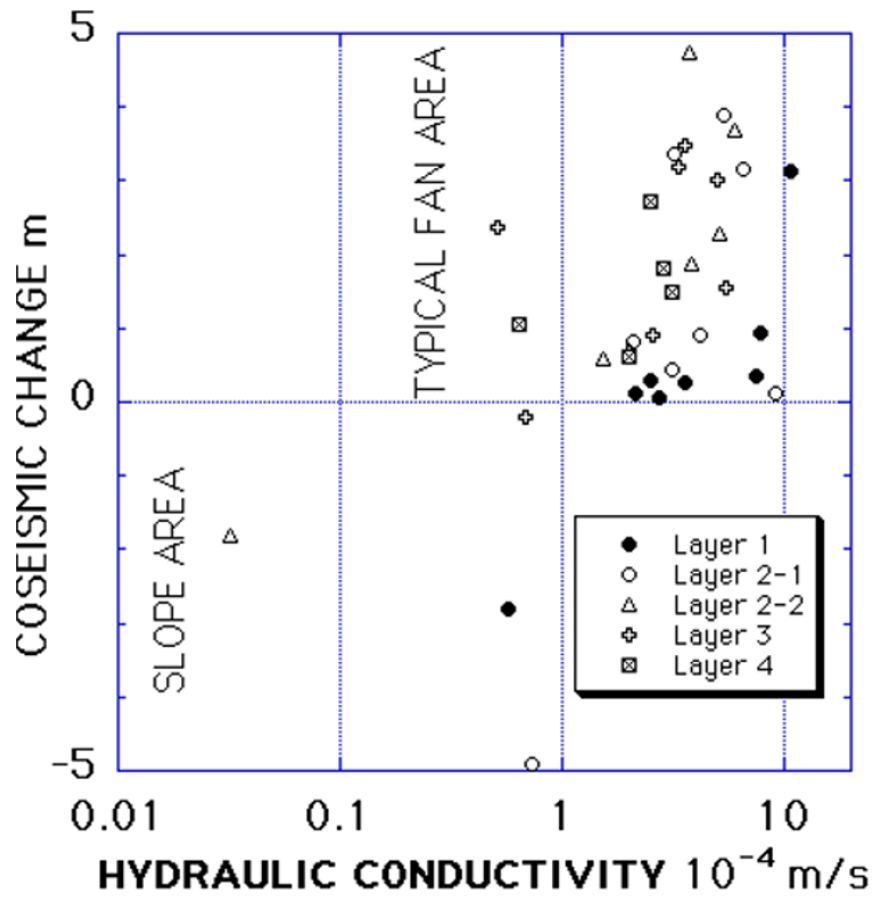

Fig. 5. Comparison of the average hydrological conductivities (Table 1) to the average coseismic groundwater level changes (Table 2). For each layer, larger hydraulic conductivities tend to produce bigger coseismic rises in the typical fan area.

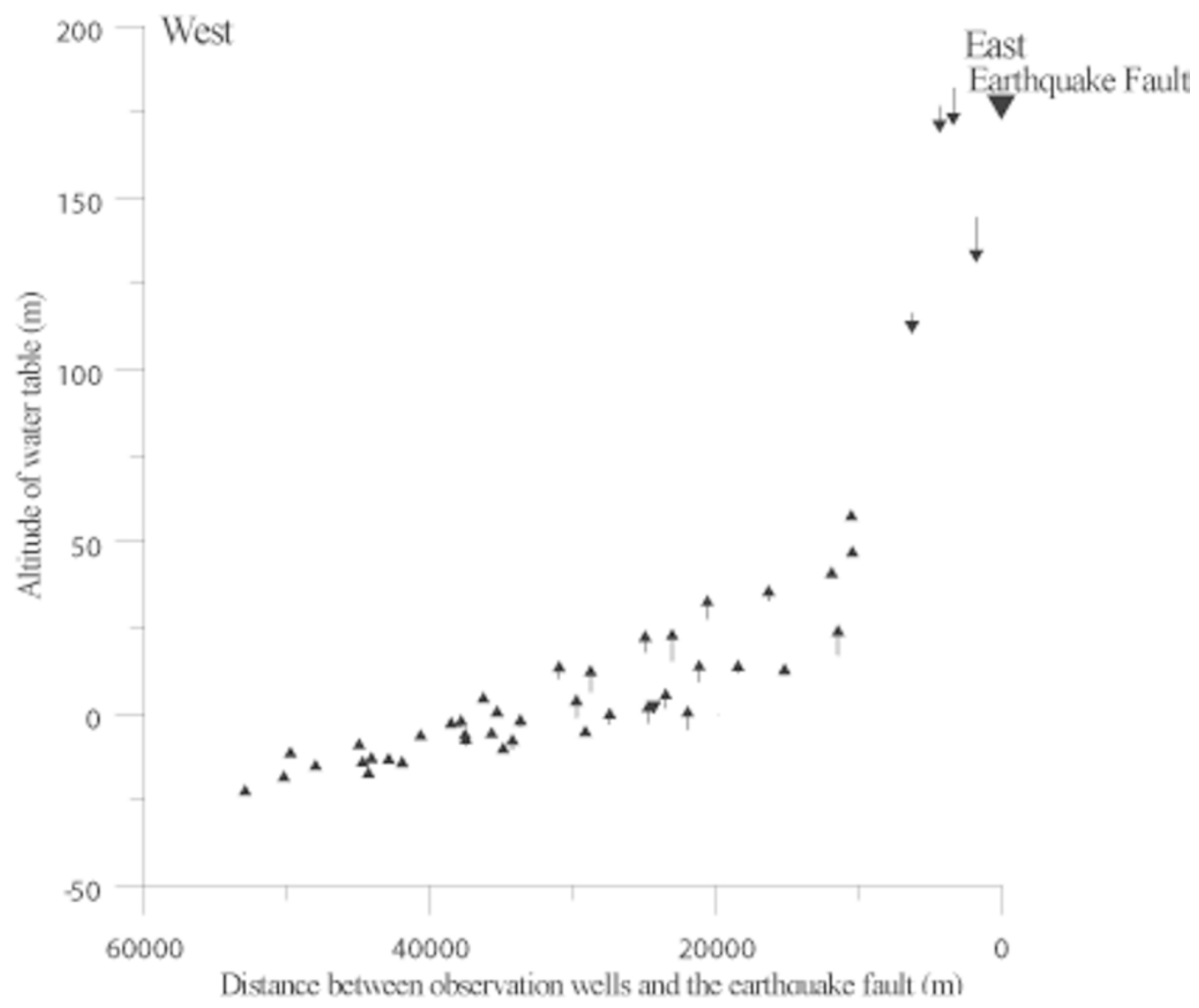

Fig. 6. Relation among the coseismic water level changes, original altitude of the water tables and distance between the observation well and earthquake fault. The coseismic changes are shown by the arrows. 


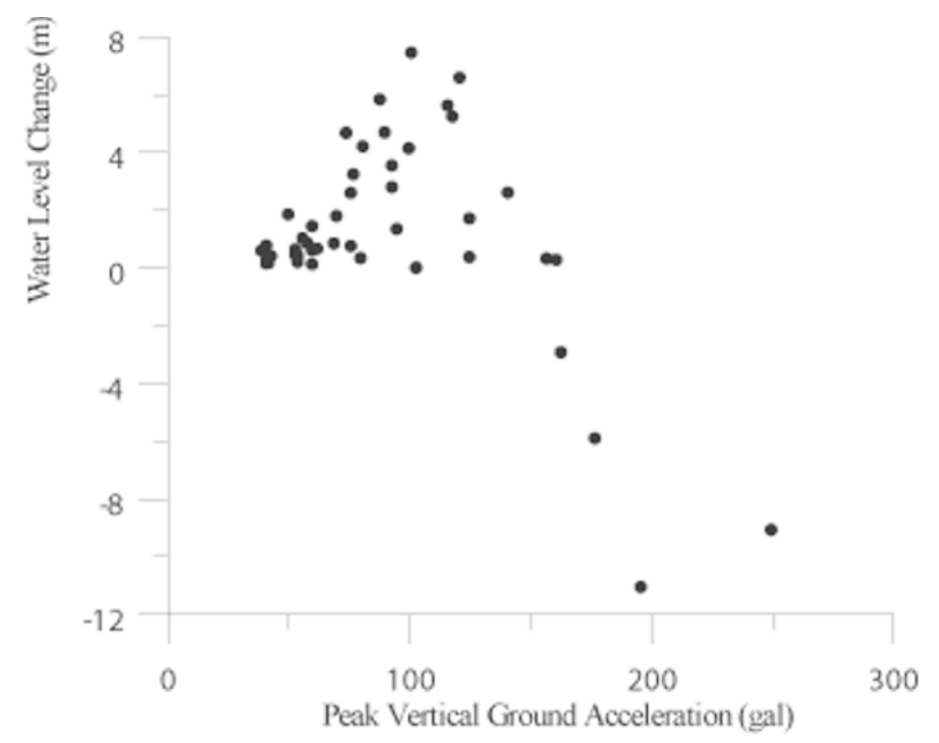

(a)

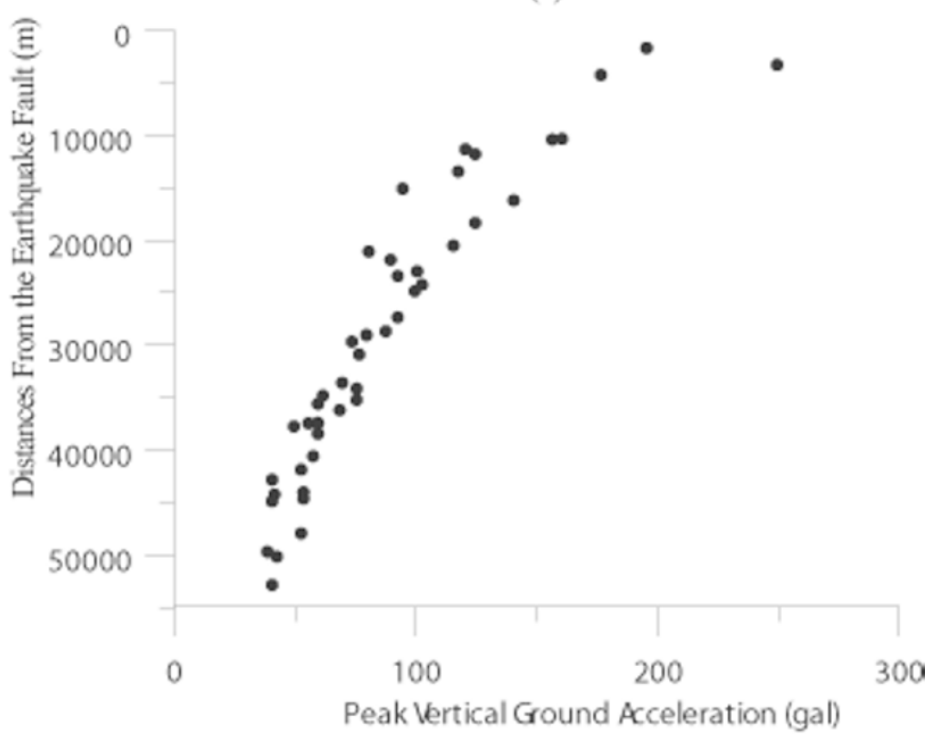

(b)

Fig. 7. (a) The groundwater level changes with the peak vertical ground acceleration of the Choshui River alluvial fan's layer 2-1. (b) Peak vertical ground accelerations with the distances between the observation wells and earthquake fault. The acceleration data are derived from the Central Weather Bureau (1999).

acceleration is closely related to the distances between the wells and the earthquake fault (Fig. 7(b)). In the area of the coseismic rise, where the distance is larger than $10 \mathrm{~km}$, the amplitudes of the coseismic rises are well related to the ground acceleration. This area is a typical fan area, where liquefaction easily occurred. In the coseismic drops in the slope area, where the distance is smaller than $10 \mathrm{~km}$, the amplitudes of the coseismic drop seem to be well related to the ground acceleration. This slope area has thinner sediments than a typical fan area (Fig. 2). Therefore the degree of liquefaction might be smaller. However, the degree of permeability enhancement might become larger because the basement, where the permeability enhancement happens more easily than in soft sedimentary layers, is shallower. The liquefaction in the fan area and permeability enhancement in the slope area caused by seismic shaking are considered to explain the pattern of those coseismic changes. In the boundary area between the typical and slope areas around the distance of $10 \mathrm{~km}$, those relationships between coseismic changes and ground acceleration is not very clear because both factors of the liquefaction and permeability enhancement might work on the groundwater level in the boundary area.

\section{Conclusion}

In this study, we compare the coseismic groundwater level changes with seismic ground motion and geological setting. The results are as follows; (1) in the typical fan area, the coseismic rises became larger as the ground acceleration and hydraulic conductivity increased; (2) in the slope area, the coseismic falls became larger as the ground acceleration increased; (3) in fine-grained aquifers of the southern part, the coseismic changes were smaller. The liquefaction and permeability enhancement, whose degrees depend on the geological setting and seismic ground motion, might explain 
the characteristics of the coseismic groundwater changes in the Choshui River alluvial fan.

Acknowledgments. We greatly thank Dr. E. Roeloffs for her helpful advice.

\section{References}

Carrigan, C. R., G. C. P. King, G. E. Barr, and N. E. Bixler, Potential for water table excursions induced by seismic events at Yucca Mountain, Nevada, Geology, 19, 1157-1160, 1991.

Central Weater Bureau, PGA data of Chi-Chi earthquake and site description, http://www.cwb.gov.tw/V4e/index.htm, 1999.

Chen, W. F. and P. B. Yuan, A preliminary study on sedimentary environments of Choshui fan-delta, Proceedings of the Geological Society of China, 42, 269-288, 1999.

Chia, Y., Y. S. Wang, J. J. Chiu, and C. W. Liu, Changes of groundwater level due to the 1999 Chi-Chi earthquake in the Choshui River alluvial fan in Taiwan, Bull. Seismol. Soc. Am., 91, 1062-1068, 2001.

Hsu, S. K., C. V. Chin, and L. H. Cheng, The result of first stage of "Groundwater Monitoring Network Plan in Taiwan". Proceeding of water resources management in 21st contrary, 177-197, 2000 (in Chinese).

Inverson, R. M. and J. J. Major, Groundwater seepage vectors and the potential for hillslope failure and debris flow mobilization, Water Resources Research, 22, 1543-1548, 1986.

Iwasaki, T. and R. Sato, Strain field in a semi-infinite medium due to an inclined rectangular fault, J. Phys. Earth, 27, 285-314, 1979.

Koizumi, N., W.-C. Lai, Y. Kitagawa, and N. Matsumoto, Comments on "Coseismic hydrological changes associated with dislocation of the September 21, 1999 Chichi earthquake, Taiwan" by Min Lee et al., Geophys. Res. Lett., 31, L13603, doi:10.1029/2004GL019897, 2004.

Lee, M., T. K. Liu, K. F. Ma, and Y. M. Chang, Coseismic hydrological changes associated with dislocation of the September 21, 1999 Chichi earthqauke, Taiwan, Geophys. Res. Lett., 29(17), 1824, doi:10.1029/2002GL015116, 2002.
Ma, K. F., J. Mori, S. J. Lee, and S. B. Yu, Spatial and temporal distribution of slip for the 1999 Chi-Chi, Taiwan, earthqauke, Bull. Seismol. Soc. Am., 91, 5, 1069-1087, 2001.

Roeloffs, E., Hydrologic precursors to earthquakes: A review, Pure Appl. Geophys., 126, 177-209, 1988.

Roeloffs, E., Poroelastic methods in the study of earthquake-related hydrologic phenomena, in Advances in geophysics, San Diego, California, edited by R. Dmowska, Academic Press, pp. 135-195, 1996.

Rojstaczer, S., and S. Wolf, Permeability changes associated with large earthquakes: An example from the Loma Prieta, California, Geology, 20, 211-214, 1992.

Sato, T., R. Sakai, K. Furuya, and T. Kodama, Coseismic spring flow changes associated with the 1995 Kobe earthquake, Geophys. Res. Lett., 27, 1219-1222, 2000.

Shin, T. C., K. W. Kuo, T. L. Lee, T. L. Teng, and Y. B. Tsai, A preliminary report on the 1999 Chi-Chi (Taiwan) earthquake, Seismological Research Letter, 71, 24-30, 2000.

Todorovska, M. I. and M. D. Trifunac, Liquefaction opportunity mapping via seismic wave energy, Journal of Geotechnical and Geoenvironmental Engineering, 125, 1032-1042, 1999.

Wakita, H., Water wells as possible indicators of tectonic strain, Science, 189, 553-555, 1975.

Wang, C. Y., L. H. Cheng, C. V. Chin, and S. B. Yu, Coseismic hydrologic response of an alluvial fan to the 1999 Chi-Chi earthquake, Taiwan, Geology, 29, 831-834, 2001.

Water Conservancy Agency, MOEA, The report of surface water and groundwater level changes in the Chi-Chi earthquake, GPN: 008854890121, 2000 (in Chinese).

Water Resources Bureau, Compilation of the result of first stage of "Groundwater Monitoring Network in Taiwan”, 1999 (in Chinese).

W.-C. Lai, N. Koizumi (e-mail: koizumi-n@aist.go.jp), N. Matsumoto, Y. Kitagawa, C.-W. Lin, C.-L. Shieh, and Y.-P. Lee 